\title{
The Effect of Online Learning Using Online Media On Learning Achievement
}

\author{
Dona Fitriawan ${ }^{1}$, Endar Sulistyowati ${ }^{2}$ \\ Mathematics Education FKIP Tanjungpura University ${ }^{1}$ \\ Economy Education STKIP Kumala Metro Lampung ${ }^{2}$ \\ Email: donafitriawan@fkip.untan.ac.id¹, endar.sulistyowati@kumala.ac.id ${ }^{2}$
}

\begin{abstract}
Abstrak. Tujuan penelitian ini untuk mengetahui pengaruh pembelajaran daring menggunakan media online terhadap prestasi belajar. Masalah dari penelitian ini adalah adanya pembatasan dalam setiap kegiatan di luar rumah. Dampak positif dari pembatasan ini dapat dimaknai dari kondisi praktisi pendidikan maupun peserta didik dalam melaksanakan kegiatan akademik dengan bekerja dari rumah yang membuat setiap individu yang melakukan aktivitasnya menjadi lebih mandiri dalam memaksimalkan pemanfaatan teknologi dan informasi. Sebelumnya, tidak semua individu memiliki kebiasaan bekerja berbasis IT, Namun kondisi ini membuat para praktisi maupun peserta didik bisa lebih terbiasa dan terampil menyelesaikan pekerjaan dengan IT. Hal ini menunjukkan moment social distancing ini membuahkan hasil peningkatan kreativitas dan kompetensi dalam pelaksanaan tugas masing-masing. Jenis penelitian ini menggunakan metode diskriptif kuantitatif dan subyek penelitian ini adalah mahasiswa semester 4 di STKIP Kumala Lampung Metro yang dilakukan secara online. Pada penelitian tersebut media online yang digunakan diantaranya aplikasi seperti google classroom, whatsapp dan youtube. Hasil penelitian ini menunjukan nahwa nilai t hitung untuk Media online adalah 4.012 dengan tingkat signifikansi 0,001 maka variabel Media online berpengaruh secara positif dan signifikan terhadap dengan nilai t hitung $(4,012)>t$ tabel $(2,101)$ dan nilai signifikan $(0,001)<0,05$. Sehingga dapat disimpulkan bahwa ada pengaruh signifikan antara variabel media online $(\mathrm{X})$ terhadap prestasi belajar $(\mathrm{Y})$. Hasil penelitian ini diharapkan dapat memberikan manfaat bagi dosen dan mahasiswa tentang bagaimana cara menciptakan suasana belajar yang kondusif tanpa harus bertatapan langsung atau berkumpul bersama-sama, sebagaimana anjuran pemerintah dalam menanggulangi menyebaran pandemi Covid 19.
\end{abstract}

Kata Kunci: Media Online, Pembelajaran Daring, Prestasi Belajar

\begin{abstract}
The purpose of this study was to determine the effect of online learning using online media on learning achievement. The problem with this research is that there are limitations in any activities outside the home. The positive impact of this limitation can be interpreted from the condition of educational practitioners and students in carrying out academic activities by working from home which makes each individual who carries out his activities become more independent in maximizing the use of technology and information. Previously, not all individuals had the habit of working based on IT, but this condition made practitioners and students more accustomed and skilled in completing work with IT. This shows that this moment of social distancing has resulted in increased creativity and competence in carrying out their respective duties. This type of research uses descriptive quantitative methods and the subjects of this research are 4th semester students at STKIP Kumala Lampung Metro which is conducted online. In this study, the online media used included applications such as Google Classroom, WhatsApp and YouTube. The results of this study indicate that the t-count value for online media is 4.012 with a significance level of 0.001 then the online media variable has a positive and significant effect on the $t$-value (4.012) $>$ t table (2.101) and the significant value $(0.001)<0.05$. So it can be concluded that there is a significant influence between online media variables $(X)$ on learning achievement $(Y)$. The results of this study are expected to provide benefits for lecturers and students on how to create a conducive learning atmosphere without having to meet face to face or gather together, as recommended by the government in tackling the spread of the Covid 19 pandemic.
\end{abstract}

Keywords: Online Media, Online Learning, Learning Achievement

\section{A. Introduction}

Educational problems always arise along with the development and improvement of students' abilities, the situation and conditions of the surrounding environment and the ability of teachers to manage learning, the influence of information, culture and advances in science 
and technology. The industrial revolution 4.0 in the education aspect is a response to needs, in this revolution where technology and humans are adapted to create new opportunities in an innovative and creative way. The role of educators who must play a role to support these transitional times. Because, we are consciously not even aware that we have entered a new era, where that era is the era of society 5.0 which is a continuation of the 4.0 revolution era. The era of society 5.0 has an understanding, namely the era that was initiated by the Japanese government for the first time with a new program and idea, namely that society is humancentered and always technology-based based on the cultural customs of the people in the era. revolution 4.0. Therefore, to face society 5.0 new ideas are needed in an effort to face the challenges that will occur in society 5.0. (Vania Sasikirana \& Herlambang, 2017); (Faulinda \& Aghni Rizqi Ni'mal, 2020).

During the Covid 19 Pandemic, Indonesia experienced difficulties, and the government urged Indonesians to stay at home. The Covid-19 pandemic has an impact not only on the social and economic fields, but also on the education system. Learning that was previously carried out face-to-face becomes learning instead of face-to-face through the network in this way. online learning method is also called e-learning or online learning (Andiani \& Fitria, 2021); (Fitriawan et al., 2021). This certainly has a big impact on all life in the world, including the world of education. Thus forcing educational institutions to change student learning methods from faceto-face methods to distance learning methods (A et al., 2020); (Ichsan et al., 2020).

In (Ju et al., 2020) online learning is a program for implementing online teaching and learning so that it can reach a massive and broad target group. Next (Andiani \& Fitria, 2021), said that the online learning process is a teaching and learning process that uses internet network facilities known as the online teaching and learning process. Online teaching and learning methods can be used to introduce formal education in schools where students and teachers are in different places, so it is necessary to use an integrated telecommunications system as a means of communication and access to various resources. (Sobron dkk, 2019).

The positive impact of this restriction can be interpreted from the condition of educational practitioners and students in carrying out academic activities by working from home or work from home (WFH). WFH make every individual who carries out his activities become more independent in maximizing the use of technology and information. Previously, not all individuals had the habit of working based on information technology. However, this condition made practitioners and students more accustomed and skilled in completing work with information technology. This shows that this moment of social distancing has resulted in increased creativity and competence in carrying out their respective duties (Yodha et al., 2019); (Sulistyowati, 2016).

In addition to these positive impacts, the negative impacts of social restrictions can be seen in the limitations of educational practitioners and students in responding to conditions. Personal readiness requires assistance and even special guidelines to understand information technology as the preferred path of work. The basic abilities that are very diverse in these individuals ultimately give rise to responses that are not uniform and have the potential to create gaps in the achievement of learning goals or targets. Another problem that often occurs is that online learning requires media and internet networks, while not all regions have a good internet network to support online learning (Maulidina et al., 2021); (Wardah, 2014).

Previous research on online learning media, namely: 1) (Andiani \& Fitria, 2021), This study aims to find out how online learning (on the network) with online media during the Covid19 pandemic is for students at SD Negeri 103 Palembang. The results of the study found that the online media used by the students where the research was carried out included Whatsapp groups, Youtube, and Quizziz. The use of online media is considered quite effective in learning for students at SD Negeri 103 Palembang; 2) (Elisvi et al., 2020), This study aims to find out the picture of online learning from home for students of SMK IT Rabbi Radhiyya using a 
qualitative approach. This study concluded that the application of online learning during the work from home covid 19 pandemic as a learning medium at the IT Rabbi Radhiyya Rejang Lebong Vocational School was running smoothly; 3) (Azis, 2015), This study aims to obtain an overview of the implementation of online learning at the Biology Education Study Program, FKIP Jambi University as an effort to suppress the spread of COVID-19 in universities. The results show that: students already have the basic facilities needed to take part in online learning, online learning has flexibility in its implementation and is able to encourage the emergence of independent learning and motivation to be more active in learning; and distance learning encourages the emergence of social distancing behavior and minimizes the emergence of student crowds so that they are considered to reduce the potential for the spread of Covid 19 in the university environment.

This study itself aims to determine the effect of online learning using online media on student achievement at STKIP Kumala Lampung Metro. Cooperation between educators and students is very much needed, lecturers act as facilitators while students must think critically to explore their abilities and be creative in producing works with such learning. Video Call applications on Whatsapp groups and videos about learning on YouTube can be a means of doing distance learning, and the Google Classroom application is a place for giving and collecting assignments given by lecturers. This type of online learning will help students become more independent. This is because students only focus on the screen to complete the task or continue the conversation all that was discussed during the teaching and learning process.

\section{B. Research Metodhology \\ In the research methodology section, it will be explained about: \\ Design}

This type of research is descriptive quantitative which means research that seeks to describe a symptom of events and events at the present time and reveals data that has taken place without manipulating other variables without affecting the dependent variable.

\section{Research Subject}

The subjects in this study were all 4th semester students of economic education, totaling 10 students as the control group and 10 students as the experimental group. The implementation time is the odd semester of the 2020/2021 academic year. The research location is STKIP Kumala Lampung Metro.

\section{Data Collection Instruments and Technique}

The research instruments used were observation sheets, questionnaire sheets and written tests and online interviews. Then, Data collection techniques using observation techniques, questionnaire techniques and online interviews.

\section{Data Analysis Technique}

The data analysis technique of the test results of the learning achievement test was analyzed by means of content validity, reliability, difficulty, discriminatory and internal consistency tests. The validity test of each test item was used with the Kark-Pearson Product Moment correlation technique at the $5 \%$ sig level. Test the reliability of the instrument using the Cronbach Alpha formula. With the help of SPSS 22, the reliability coefficient is 0.7 . The analysis prerequisite test consists of a normality test and a homogeneity test. The normality test was carried out using the Lilliefors-Kolmogrov Smirnov method and the results were that all data groups were normally distributed. The homogeneity test used Levene's test and the results were all groups of homogeneous variance data. Meanwhile, to test the hypothesis using simple linear regression analysis. The calculation uses the coefficient of determination (Adjusted R2), simultaneous test ( $F$ test) and partial test ( $\mathrm{T}$ test) and the results show that there is a positive influence between online media $(\mathrm{X})$ and learning achievement $(\mathrm{Y})$. 


\section{Results and Discussion}

The main results of the study will be presented in the following results and discussion.

\section{Results and Findings}

To find out and at the same time test the effect of online learning using online media on learning achievement at STKIP Kumala Lampung Metro, a checklist (questionnaire) was used with ten question items and multiple-choice written test questions. The research data was obtained from the results of tests and questionnaires.

\section{Validity test}

In this study, the validity test used was Pearson correlation. Validity test was conducted to measure the statements in the questionnaire. Thus, based on the validity test, a statement item is said to be valid if the rcount value of the item's score to its total score is above 0.378 or it is said to be invalid if the rcount value of the statement item is less than 0.378 . Therefore, the better the Pearson correlation coefficient of an item, the better the validity of the item. It is known that all items score statements about online media have an rcount value greater than rtable $=0.378$. Thus, it can be said that all statement items regarding online media are valid and can be used as research measuring tools.

\section{Reliability Test}

The reliability test is used to determine whether or not the data from the respondents used in this study is feasible. Each variable has a minimum value, maximum value, average value (mean) and standard values that vary. Online media (X) has a minimum value of 29.00 and a maximum value of 45.00 , the average online media is 37,3500 and the standard deviation is 5,21410. Meanwhile (Y) has a minimum value of 22.00 and a maximum value of 44.00 , the average is 32.0000 with a standard deviation of 5.12989 .

\section{Normality Test}

A good regression model is one that has a normal or close to normal data distribution. The normality of the data in the regression model is carried out with a normality test. Significant probability value that all variables are valued above $5 \%$ or 0.05 . The online media variable produces $Z$ of 0.848 with $P>0.05$, which is 0.468 . While the Financial Responsibility Report Material variable produces $Z$ of 0.763 with $P>0.05$, which is 0.605 . Based on these results, it can be said that the distribution of scores for the two variables is normal.

\section{Linearity Test}

Linearity test was conducted to see the level of correlation between the independent variable and the dependent variable. Whether or not a relationship is linear, it can be seen from the probability of error of $\mathrm{P}$ being different, namely through the value of $\mathrm{F}$ in the source of differences between groups. The relationship between the two variables is said to be linear if $P$ $<0.05$ and non-linear if $\mathrm{P}>0.05$.

\section{Hypothesis Testing}

The results of the normality and linearity tests showed that the collected data met the requirements for further analysis, namely using simple linear regression analysis to test the proposed hypothesis. Linear regression of linear equations, which involves one independent variable to be used as a predictor of the value of the dependent variable.

\section{Coefficient of Determination Test Results}

The coefficient of determination (Adjusted R2) measures how far the model's ability to describe the variation of the dependent variable. The value of Adjusted R2 which is close to one means that the independent variables provide almost all the information needed to predict the variation of the dependent variable. The results of the coefficient of determination test (Adjusted R2) can be seen in Table 1. 
Table 1 Coefficient of Determination Test Results (Adjusted R2)

\begin{tabular}{|c|c|c|c|c|}
\hline Model & R & R Square & Adjusted R Square & Std. Error of the Estimate \\
\hline 1 & $.681^{\mathrm{a}}$ & .464 & .434 & 3.86033 \\
\hline
\end{tabular}

Based on Table 1, it can be seen that in this study there is a positive relationship between online media and Financial Accountability Report Material. Based on the results of hypothesis testing with regression analysis, the value of $r$ is 0.681 with $p<0.05$. This means that there is a significant positive relationship between online media and Financial Accountability Report Material, and it can be interpreted that the hypothesis is accepted.

The coefficient of determination is 0.464 so it can be interpreted that the influence of online media variables on Financial Accountability Report Material is $46 \%$. Based on the overall analysis results from the simple linear regression test in this study, it can be concluded that the hypothesis in this study is accepted or proven.

\section{Simultaneous Test Results (F Test)}

Simultaneous test (F test) basically shows whether all independent variables included in the model have a simultaneous effect on the dependent variable. The results of the F test can be seen in Table 2.

Table 2 F Test Result

\begin{tabular}{|c|c|c|c|c|c|c|}
\hline \multicolumn{2}{|c|}{ Model } & Sum of Squares & Df & Mean Square & F & Sig. \\
\hline \multirow{2}{*}{1} & Regression & 231.761 & 1 & 231.761 & 15.552 & $.001^{\mathrm{a}}$ \\
\cline { 2 - 7 } & Residual & 268.239 & 18 & 14.902 & & \\
\cline { 2 - 7 } & Total & 500.000 & 19 & & & \\
\hline
\end{tabular}

Based on Table 2, it can be seen that the significant value is $0.01<\mathrm{a}=0.05$. The results of this analysis are strengthened by looking for the value of the F table with the value of $\mathrm{df}(\mathrm{n} 1)$ $\mathrm{df}(\mathrm{n} 2)=18$, and a significance level of 0.05 , so the $\mathrm{F}$ table value is 4.41 , the calculated $\mathrm{f}$ value $(15.552)>\mathrm{f}$ table (4.41) and significant $0.001<\mathrm{a}=0.05$. The results of the $\mathrm{F}$ test show that all independent variables (online media) simultaneously have a significant effect on the dependent variable (Financial Accountability Report Material).

\section{Partial Test Results (t Test)}

Partial test ( $t$ test) basically shows how far one independent variable individually or partially can explain the variation of the dependent variable. The results of the $t$ test can be seen in Table 3.

Table 3. $t$ Test Result

\begin{tabular}{|c|c|c|c|c|c|c|}
\hline \multirow{2}{*}{ Model } & \multicolumn{2}{|c|}{ Unstandardized Coefficients } & Standardized Coefficients & \multirow{2}{*}{ T } & \multirow{2}{*}{ Sig. } \\
\cline { 3 - 7 } & B & Std. Error & Beta & & \\
\hline \multirow{2}{*}{1} & (Constant) & 6.140 & 6.502 & & .944 & .358 \\
\cline { 2 - 7 } & Media online & .694 & .173 & .687 & 4.012 & .001 \\
\hline
\end{tabular}

Source: Research results using SPSS 16.0 for windows

Based on Table 3, it can be concluded that the results of the significance or influence of the independent variables on the dependent variable that the $t$ value for online media is 4,012 with a significance level of 0.001 then the online media variable has a positive and significant effect on the $t$ value $(4.012)>t$ table $(2.101)$ and significant value $(0.001)<0.05$. The significant value of the variable. 
Online media $(\mathrm{X})$ is smaller than 0.05 which means it has a significant effect on $(\mathrm{Y})$. The online media variable has a positive and significant effect on. So that the regression equation can be arranged as follows:

\section{Discussion}

$$
\begin{gathered}
Y=a+b X \\
Y=6.140+0,694 X
\end{gathered}
$$

Based on the results of research and interviews that have been conducted online on STKIP Kumala Lampung students, that there is a positive influence between online learning and student learning outcomes. This is evidenced by the results of the significance or effect of the independent variables on the dependent variable, that the $t$ value for online media is 4,012 with a significance level of 0.001 , the online media variable has a positive and significant effect on the $t$ value $(4.012)>t$ table $(2.101)$. and significant value $(0.001)<0.05$. The significant value of the online media variable $(\mathrm{X})$ is smaller than 0.05 , which means it has a significant effect on (Y). . This is evidenced by the results of the significance or effect of the independent variables on the dependent variable, that the $t$ value for online media is 4,012 with a significance level of 0.001 , the online media variable has a positive and significant effect on the $t$ value (4.012) $>t$ table $(2.101)$. and significant value $(0.001)<0.05$. The significant value of the online media variable $(\mathrm{X})$ is smaller than 0.05 , which means it has a significant effect on $(\mathrm{Y})$.

This also proves the research conducted (Syafari, Yusneli., Montessori, Maria, 2021) who found that online learning basically makes it easier for students to carry out the teaching and learning process without having to meet face to face or gather together, as recommended by the government in tackling the spread of the Covid-19 virus. As a consequence of all that, educators are the spearhead of achievement and create an atmosphere of teaching and learning activities with a learning mission. Educators are also a central point for planning, organizing in order to achieve the mission of national education and the mission of the institution.

Learning on the online network is carried out due to the Covid 19 virus pandemic. This provides positive energy for lecturers and students as they become more mastered and develop skills related to technology to help the learning process (Puspitasari et al., 2021). Acording to (Ayuni et al., 2020), in general, the goal of online learning is to provide a very large quality online learning service that is accessible to a wider audience. Due to the potential to provide more accessible content access services, online learning is now becoming popular, thus providing many advantages in its implementation.

From various studies that have been conducted by previous researchers, the advantages of online learning according to (Ayuni et al., 2020): (a) increasing the standard of education and training (b) the efficiency of using multimedia in learning (c) increasing the availability of quality education and training by including online learning (d) reduce costs to provide quality training and education using shared resources. In addition to the advantages mentioned above, (Anugrahana, 2020) mentions the disadvantages of using e-learning, including: a) Lack of faceto-face meetings between students and teachers or between students; b) The learning carried out tends to be more in the form of training than education; and c) The business or industrial aspect is more visible than the social aspect; (d) Teachers should be trained in the use of technology, particularly information and communication technology. (e) unequal data systems in areas with problems with power, telephone and computers; f) human resources who are still less skilled in running computers; g) machine language that has not been mastered; h) Students may feel alienated; i) the quality and accuracy of the data has changed, requiring guidance when answering questions; j) Students are not satisfied because they cannot see graphics, pictures, or videos because the equipment does not work.

In practice, the results of this study provide benefits for both students and lecturers. This learning process takes place in collaboration between lecturers and students, so that lecturers can easily transfer information and students can easily capture, understand and transform this 
information in their learning. During online learning with online media, students work on the questions given by the lecturer well. The Covid 19 pandemic period did not hinder students' motivation in conducting online learning activities. Students who have high learning motivation have the desire to get good grades so that to achieve these goals students study well and diligently. High student learning outcomes can be seen based on indicators, one of which is related to concentration, according to (Nurhayati et al., 2020); (Fitriawan et al., 2021), that concentration will make students understand the material being taught. This is based on the fact that attention will be focused on what is attracting students.

A similar study was also put forward by (Sadikin \& Hamidah, 2020), who said that in the midst of the Covid 19 pandemic that hit the world, this was not a reason for students to have high learning motivation, even though in In its implementation there are deficiencies found, but there is no other choice but to optimize online learning, because in an emergency like this, only technology is the bridge in the transfer of knowledge from lecturers to students. Another benefit of online learning is that it also allows students to have the flexibility of learning time so they can study anytime and anywhere. Students learn with ease because they can make assignments anywhere. In addition, students can interact with lecturers using several applications such as google classroom, Whatsapp videos, Youtube or through whatsapp groups (Nurhayati et al., 2020). Several studies have explained that there is a significant relationship between learning independence and learning outcomes both in direct learning and in distance learning (Nurhayati et al., 2020); (Tahar, 2006).

\section{Conclution and Suggestion Conclusion}

From the results of the research and discussion, it is concluded that there is a significant effect between online learning and online media on learning achievement which is obtained from the $t$ arithmetic value $(4.012)>t$ table $(2.101)$ and a significant value $(0.001)<0.05$. The significant value of the online media variable $(\mathrm{X})$ is less than 0.05 , which means it has a significant effect on (Y). It is concluded that there is a positive influence between online learning and student learning outcomes. Students are quite able to adapt to the online learning system in the midst of the Covid 19 pandemic.

\section{Suggestion}

The advice given is that every individual must be responsive to the limitations during the pandemic to remain productive and creative and interpret this pandemic condition as part of a change that still has to prioritize representative attitudes and behaviors in the new order to create varied learning spaces. This means that the better learning with the online method provided, the better the learning outcomes of students.

The researcher realizes that this research is still far from perfect, so it still requires followup from other researchers to be able to complete the shortcomings. We also express our gratitude to the STKIP Kumala Lampung Metro students who were directly involved in this research and to other parties who indirectly helped in writing this article. We would like to express our gratitude to all colleagues and students at STKIP Kumala Metro Lampung who have helped carry out this research.

\section{REFERENCES}

A, J. C., B, K. B., \& H, S. L. (2020). COVID-19: 20 countries' higher education intra-period digital pedagogy responses. Journal of Applied Learning \& Teaching, 3(1). 
https://doi.org/10.37074/jalt.2020.3.1.7

Andiani, W., \& Fitria, H. (2021). Pembelajaran Daring Menggunakan Media Online Selama Pandemi Covid-19 Pada Siswa Sd Negeri 103. 172-181.

Anugrahana, A. (2020). Hambatan, Solusi dan Harapan : Pembelajaran Daring Selama Masa Pandemi Covid-19 Oleh Guru Sekolah Dasar. Scholaria: Jurnal Pendidikan Dan Kebudayaan, 10(3), 282-289.

Ayuni, D., Marini, T., Fauziddin, M., \& Pahrul, Y. (2020). Kesiapan Guru TK Menghadapi Pembelajaran Daring Masa Pandemi Covid-19. Jurnal Obsesi : Jurnal Pendidikan Anak Usia Dini, 5(1), 414. https://doi.org/10.31004/obsesi.v5i1.579

Azis, A. A. (2015). Pengembangan Media E-Learning Berbasis LMS Moodle pada Matakuliah Anatomi Fisiologi Manusia. Jurnal Pendidikan Biologi, 7(1), 1-8. http://journal2.um.ac.id/index.php/jpb/article/view/712

Elisvi, J., Archanita, R., Wanto, D., \& Warsah, I. (2020). Analisis Pemanfaatan Media Pembelajaran Online Di Smk It Rabbi Radhiyya Masa Pandemi Covid-19. Al-Tarbawi AlHaditsah: Jurnal Pendidikan Islam, 5(2), 16-42. https://doi.org/10.24235/tarbawi.v5i2.6721

Faulinda, E. N., \& Aghni Rizqi Ni'mal, 'Abdu. (2020). Kesiapan Pendidikan Indonesia Menghadapi era society 5.0. Edcomtech: Jurnal Kajian Teknologi Pendidikan, 5(1), 6166.

Fitriawan, D., Siregar, N., Pasaribu, R. L., \& Tanjungpura, U. (2021). Problematika dalam menilai sikap peserta didik pada pembelajaran daring. Prosiding Seminar Nasional RCI, 2019-2022.

Ichsan, I. Z., Rahmayanti, H., Purwanto, A., Sigit, D. V., Irwandani, I., Ali, A., Susilo, S., Kurniawan, E., \& Rahman, M. M. (2020). COVID-19 Outbreak on Environment: Profile of Islamic University Students in HOTS-AEP-COVID-19 and PEB-COVID-19. Tadris: Jurnal Keguruan Dan Ilmu Tarbiyah, 5(1), 167-178. https://doi.org/10.24042/tadris.v5i1.6283

Ju, J., Wei, S. J., Savira, F., Suharsono, Y., Aragão, R., Linsi, L., Editor, B., Reeger, U., Sievers, W., Michalopoulou, C., Mimis, A., Editor, B., Ersbøll, E., Groenendijk, K., Waldrauch, H., Waldrauch, H., Bader, E., Lebhart, G., Neustädter, C., ... Saillard, Y. (2020). Efektivitas PembelajaranD Daring Dalam Pembelajaran Bahasa Indonesia Di Kelas II A MI Unggulan Miftahul Huda Tumang Cepogo Boyolali. Journal of Chemical Information and Modeling, 43(1), 7728. https://online210.psych.wisc.edu/wp-content/uploads/PSY210_Unit_Materials/PSY-

210_Unit01_Materials/Frost_Blog_2020.pdf\%0Ahttps://www.economist.com/specialreport/2020/02/06/china-is-making-substantial-investment-in-ports-and-pipelinesworldwide\%0Ahttp://

Maulidina, L., Mardiana, T., \& Supriyatna, A. (2021). Analisis Metode Pembelajaran Ipa Dalam Pembelajaran Jarak Jauh Saat Wabah Covid-19 Di Sekolah Dasar. Khazanah Pendidikan, 15(1), 42. https://doi.org/10.30595/jkp.v15i1.9838

Nurhayati, S., Wicaksono, M. F., Lubis, R., Rahmatya, M. D., \& Hidayat, H. (2020). 
Peningkatan Kemampuan Guru Dalam Pembelajaran Daring Dengan Memanfaatkan Teknologi Informasi Bagi Guru SMA Negeri 5 Cimahi Bandung. Indonesian Community $\begin{array}{llll}\text { Service and } & \text { Empowerment }\end{array}$ https://doi.org/10.34010/icomse.v1i2.3878

Puspitasari, P., Aliviameita, A., \& Rinata, E. (2021). Korelasi Antara Profil Hematologi Dengan Procalcitonin Pada Pasien Terkonfirmasi Covid-19. The Journal of Muhammadiyah Medical Laboratory Technologist, 4(1), 66. https://doi.org/10.30651/jmlt.v4i1.7290

Sadikin, A., \& Hamidah, A. (2020). Pembelajaran Daring di Tengah Wabah Covid-19. Biodik, 6(2), 109-119. https://doi.org/10.22437/bio.v6i2.9759

Sulistyowati, E. (2016). Pengaruh Model Pembelajaran Kooperatif Tipe Two Stay Two Stray dan Numbered Head Together Terhadap Prestasi Belajar. Perpustakaan.Uns.Ac.Id, 147, $11-40$.

Tahar, I. (2006). Hubungan Kemandirian Belajar Dan Hasil Belajar Pada Pendidikan Jarak Jauh. Jurnal Pendidikan Terbuka Dan Jarak Jauh, Volume. 7, Nomor 2, September 2006, 91-101 Proses.

Vania Sasikirana, \& Herlambang, Y. T. (2017). Urgensi Merdeka Belajar Di Era Revolusi Industri 4.0 Dan Tantangan Society 5.0. Seminar Nasional: Jambore Konseling 3, 00(00), XX-XX. https://doi.org/10.1007/XXXXXX-XX-0000-00

Wardah, W. (2014). Metacognitive Reading Strategy Enhancing English Reading Comprehension. At-Turats, 8(1). https://doi.org/10.24260/at-turats.v8i1.107

Yodha, S., Abidin, Z., \& Adi, E. (2019). Persepsi Mahasiswa Terhadap Pelaksanaan E-Learning Dalam Mata Kuliah Manajemen Sistem Informasi Mahasiswa Jurusan Teknologi Pendidikan Universitas Negeri Malang. Jurnal Kajian Teknologi Pendidikan, 2(3), 181187. https://doi.org/10.17977/um038v2i32019p181 